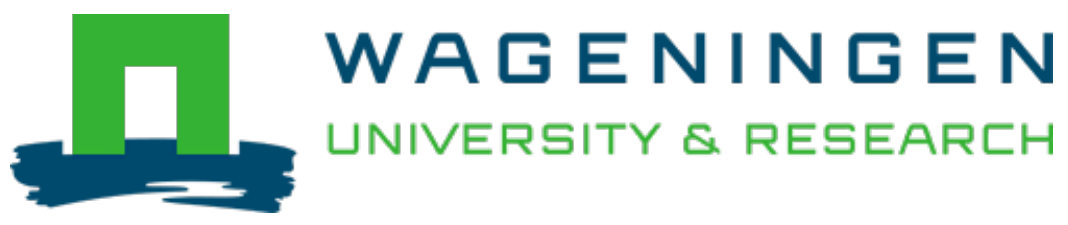

\author{
Assessing land suitability for rainfed paddy rice production in Zambia \\ Geoderma Regional \\ Makungwe, Mirriam; Chabala, Lydia Mumbi; Dijk, Michiel; Chishala, Benson H.; Lark, Murray \\ https://doi.org/10.1016/j.geodrs.2021.e00438
}

This article is made publicly available in the institutional repository of Wageningen University and Research, under the terms of article $25 \mathrm{fa}$ of the Dutch Copyright Act, also known as the Amendment Taverne. This has been done with explicit consent by the author.

Article $25 \mathrm{fa}$ states that the author of a short scientific work funded either wholly or partially by Dutch public funds is entitled to make that work publicly available for no consideration following a reasonable period of time after the work was first published, provided that clear reference is made to the source of the first publication of the work.

This publication is distributed under The Association of Universities in the Netherlands (VSNU) 'Article $25 \mathrm{fa}$ implementation' project. In this project research outputs of researchers employed by Dutch Universities that comply with the legal requirements of Article $25 \mathrm{fa}$ of the Dutch Copyright Act are distributed online and free of cost or other barriers in institutional repositories. Research outputs are distributed six months after their first online publication in the original published version and with proper attribution to the source of the original publication.

You are permitted to download and use the publication for personal purposes. All rights remain with the author(s) and / or copyright owner(s) of this work. Any use of the publication or parts of it other than authorised under article $25 \mathrm{fa}$ of the Dutch Copyright act is prohibited. Wageningen University \& Research and the author(s) of this publication shall not be held responsible or liable for any damages resulting from your (re)use of this publication.

For questions regarding the public availability of this article please contact openscience.library@wur.nl 


\title{
Assessing land suitability for rainfed paddy rice production in Zambia
}

\author{
Mirriam Makungwe ${ }^{\mathrm{a}, *}$, Lydia Mumbi Chabala ${ }^{\mathrm{a}}$, Michiel Van Dijk ${ }^{\mathrm{b}, \mathrm{d}}$, Benson H. Chishala ${ }^{\mathrm{a}}$, \\ R. Murray Lark ${ }^{\mathrm{c}}$ \\ a Department of Soil Science, School of Agricultural Sciences, University of Zambia, P.O. Box 32379, Lusaka, Zambia \\ ${ }^{\mathrm{b}}$ Ecosystems Services and Management (ESM), International Institute for Applied Systems Analysis (IIASA), Schlossplatz 1, A-2361 Laxenburg, Austria \\ ${ }^{\mathrm{c}}$ School of Biosciences, University of Nottingham, Sutton Bonington, Nottinghamshire LE12 5RD, UK \\ ${ }^{\mathrm{d}}$ Wageningen Economic Research, 528, Pr. Beatrixlaan 582, 2595 BM Den Haag, the Netherlands
}

\section{A R T I C L E I N F O}

\section{Keywords:}

Land suitability

Multi-criteria evaluation

Paddy rice

Multiple soil classes

\begin{abstract}
A B S T R A T
Rice is one of the staple food crops and is a profitable smallholder cash crop in Zambia. It has the potential to contribute significantly to increased incomes and employment among rural producers. However, rice is the only staple crop in the country for which domestic production does not meet or exceed domestic demand. Low productivity is one of the factors that contribute to this. One necessary step towards addressing this problem is the identification of land with greatest potential for rice production, as well as the identification of land-based limitations which might be overcome by improved management. The aim of this study was to develop a land suitability index for rainfed paddy rice production reflecting expert opinion and published studies based on climatic, topographic and soil properties. Land suitability was evaluated using a method which accounts for important multiple factors, and which considers their joint effect in terms of a hierarchical model of constraints. The suitability classes were ranked according to the FAO land suitability classification as: Highly Suitable (S1), Moderately Suitable (S2), Marginally Suitable (S3), Currently Not Suitable (N2), and Permanently Not Suitable (N1). Results showed that there is limited potential for rainfed paddy rice production in Zambia with $<20 \%$ of the land classified as either highly or moderately suitable. Therefore, the potential of irrigated and upland rice production in Zambia needs to be assessed as this would help expand the potential production area of rice.
\end{abstract}

\section{Introduction}

Rice, in addition to maize, cassava, sorghum, millet, wheat, sweet and Irish potato, is one of the staple food crops (Styger, 2014) in Zambia. It is a profitable smallholder cash crop with the potential to contribute significantly to increased incomes and employment among rural producers (Chizhuka, 2009). The current status of rice is evidence of its growing importance. The annual demand for rice rose steadily from below 20,000 tones to almost 70,000 tones for the period 2003-2017 as illustrated in Fig. 1 (CSO, 2018).

However, the demand for rice exceeds production, making rice the only crop in Zambia with a deficit. To meet this deficit, the country has imported between 5000 and 20,000 tons of milled rice annually (Ministry of Agriculture, 2016). In response, the government through the Ministry of Agriculture, developed the National Rice Development Strategy (NRDS) in 2016, whose overall objective was to increase local rice production by at least $50 \%$ and to enhance its competitiveness on the market by the year 2020. However, to date the national average yield of rice has not increased, neither has the area planted, although the staple requirement continues to increase (Table 1).

Poor yield is one of the factors that has contributed to Zambia's inability to meet the increasing demand for rice through local production. Average rice yields are $1.3 \mathrm{t} / \mathrm{ha}$ (CSO/MAL/RALS, 2015) which is quite low when compared to other Eastern and Southern African countries such as South Africa, Kenya, Uganda and Zimbabwe where national average yields were $2.61,5.24,2.30$ and $2.26 \mathrm{t} /$ ha respectively for the year 2013 (Ministry of Agriculture, 2016).

Apart from soil constraints (Aune et al., 2014), poor water management is also one of the factors that limits rice yields (Styger and Uphoff, 2016). Most of the rice grown in Zambia is rainfed paddy rice and this limits its cultivation to flooded or semi-flooded lowland environments (Mutale et al., 2010). With frequent occurrence of droughts, floods and other extreme weather conditions due to climate change, farmers generally find it difficult to improve production and

\footnotetext{
* Corresponding author.

E-mail addresses: mirriammakungwe.tolopu@gmail.com (M. Makungwe), lchabala@unza.zm (L.M. Chabala), Michiel.vandijk@wur.nl (M. Van Dijk), bchishala@ unza.zm (B.H. Chishala), Murray.Lark@nottingham.ac.uk (R.M. Lark).
} 


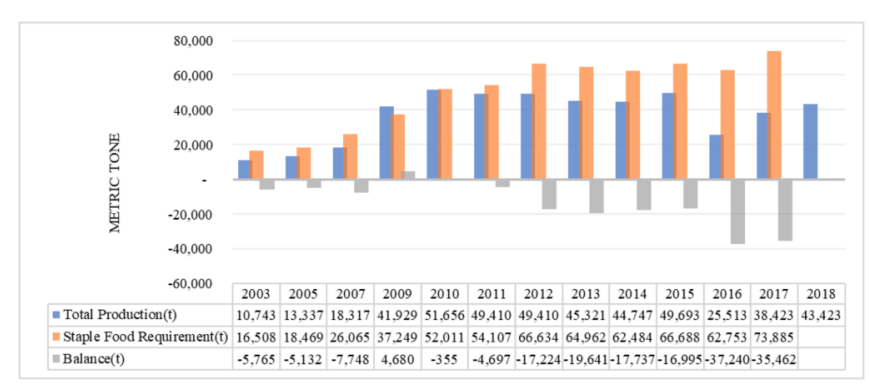

Fig. 1. Rice Production, Consumption and net-trade balance in Zambia. (Ministry of Agriculture/Central Statistical Office Crop Forecast Survey 2002/ 03-2017/18, Ministry of Agriculture Food Balance Sheets 2002/03-2017/18 https://www.zamstats.gov.zm/; https://zambia.opendataforafrica.org/etqmqg f/agriculture-statistics-2017.)

productivity (Ministry of Agriculture, 2016).

With these constraints in the production one is left with a question: How much of the land area in Zambia is suitable for rainfed paddy rice production, and where can the land be found? This question necessitates a land suitability assessment for rainfed paddy rice production.

Singha and Swain (2016) described land suitability analysis as a process of determining the appropriateness of land in a specific location for a particular use. The suitability of a particular area of land for a crop depends on various factors, some of which cannot feasibly be modified by management practices and so are absolute constraints. If we are to make effective use of land then we need to analyze these requirements, and then identify which land uses are sensible at some location of interest, or where land is suitable for particular uses of interest (Suheri et al., 2018; Agidew, 2015). Land suitability assessment can identify constraints, opportunities and potential of the land resource for a given use (Mohammed, 2011; Mokarram and Aminzadeh, 1996). It also plays an important role in sustainable agricultural practice and management (Tanasă et al., 2010) as it provides information to farmers, extension staff, policy makers and other stake holders on how suitable the land is in terms of agronomic (such as soil), climatic and other limitations (Olaleye et al., 2002). It has been integrated in studies as an aid to land use planning (Johnson et al., 1994). A new software called Land Suitability Evaluation (LSE) was developed and applied by Nguyen et al. (2020) despite this approach having advantages such as high flexibility, time savings, and higher objectivity, its main limitation is that the software runs on a raster data structure which requires considerable computer memory. Hence a researcher working with large raster files and using a smaller computer will have challenges using this software.

A review of the literature showed that there are few studies on land suitability assessment in Zambia. One study was carried out by Munene et al. (2017) to assess land suitability for soybean production in Kabwe District. The other was carried out by Chirwa et al. (2016) who evaluated the soil fertility status and suitability of land for groundnut and maize production by smallholder farmers in Chisamba District. Suitability assessment for rainfed paddy rice has never been carried out in Zambia. The aim of this study was to develop a land suitability index for rainfed paddy rice production reflecting expert opinion and published studies and based on climatic, topographic and soil properties.

\section{Methods}

This study was carried out in Zambia, a landlocked country in Southern Africa with an area of 752, $618 \mathrm{~km} 2$. The country is made up of a diverse of soil types as shown in Fig. 2 ranging from Acrisols in the northern, Arenosols in the west. It is also made up of four agroecological zones.

\subsection{Land suitability evaluation}

Land suitability evaluation may account for a range of factors that are potential constraints on the land use of interest. The FAO approach which is based on climate, soil and terrain conditions was developed from a series of expert consultation starting with a framework for land evaluation (FAO, 1976), then they developed the guidelines on Land evaluation for rainfed agriculture (FAO, 1983), followed by guidelines for Land evaluation for irrigated agriculture (FAO, 1985) and then in 2012 they worked in collaboration with IIASA (IIASA/FAO, 2012), These approaches to land evaluation can be presented as indices which indicate the dominant factors limiting land suitability for a particular use at a site. These indices may be interpreted by the expert, but they remain multi-factor and as such are not readily represented in map form at national scale for ease of interpretation by policy makers, farmer organizations or other such stakeholders. The objective of this study was therefore to develop a multi-criteria evaluation (MCE), by which information on several factors (soil and land constraints and requirements) can be used to produce a single index which can be presented as a map (Malczewski, 1999). After review of the literature (FAO, 1976; De Data, 1981; Chisci, 2009) on land suitability for rainfed paddy rice production, we identified the key soil and site factors (SSF) comprising both constraints and requirements key to evaluation. These are slope, the content, percent by volume, of coarse fragments (soil particles $>2 \mathrm{~mm}$ ), soil drainage, soil $\mathrm{pH}$, soil organic carbon (OC), soil cation exchange capacity (CEC), annual rainfall and mean temperature of the growing season.

\subsubsection{Sources and collation of information on SSF}

Basic information on the soil and land constraints and requirements identified were Slope data derived from the NASA Shuttle Radar Topography Mission (SRTM3) global 1-arcsecond (30-m) Digital Elevation Model (DEM) downloaded from USGS (2019); annual mean temperature and annual precipitation — these are averages from 1970 to 2000 with spatial resolution of $1 \mathrm{~km}$ (Fick and Hijmans, 2017). The data on soil properties was downloaded from ISRIC (2017). A summary of these data sources and formats has been given in Table 2: Hengl et al. (2017) described in detail the analytical and prediction methods that were undertaken to map these soil properties. The SoilGrids system at $250 \mathrm{~m}$ resolution was updated in June 2016 and provides global predictions for standard numeric soil properties such as OC, CEC, $\mathrm{pH}$, drainage conditions and coarse fragments. Poggio et al. (2021) carried out a quantitative evaluation of these maps. Hengl et al. (2017) undertook10-fold repeated cross-validation and showed that the ME of the models for OC, CEC, $\mathrm{pH}$ and coarse fragments were -0.292 , $0.071,-0.002$ and -0.104 respectively. While the RMSE of the models for OC, CEC, $\mathrm{pH}$ and Coarse fragment were 32.8, 10.3, 0.5 and 10.9 respectively. This cross-validation was for worldwide and not Zambia alone.

Table 1

Area planted and yield of paddy rice in Zambia (Ministry of Agriculture, 2016; Ministry of Agriculture/Central Statistical Office Crop Forecast Survey 2010/11-2017/ 18).

\begin{tabular}{llllllll}
\hline Year & 2011 & 2012 & 2013 & 2014 & 2015 & 2016 & 2017 \\
\hline Total area planted (square $\mathrm{km})$ & 339.95 & 313.88 & 385.28 & 409.74 & 429.83 & 255.94 & 333.03 \\
Yield (t/ha) & 1.45 & 1.44 & 1.16 & 1.21 & 0.59 & 342.17 \\
\hline
\end{tabular}




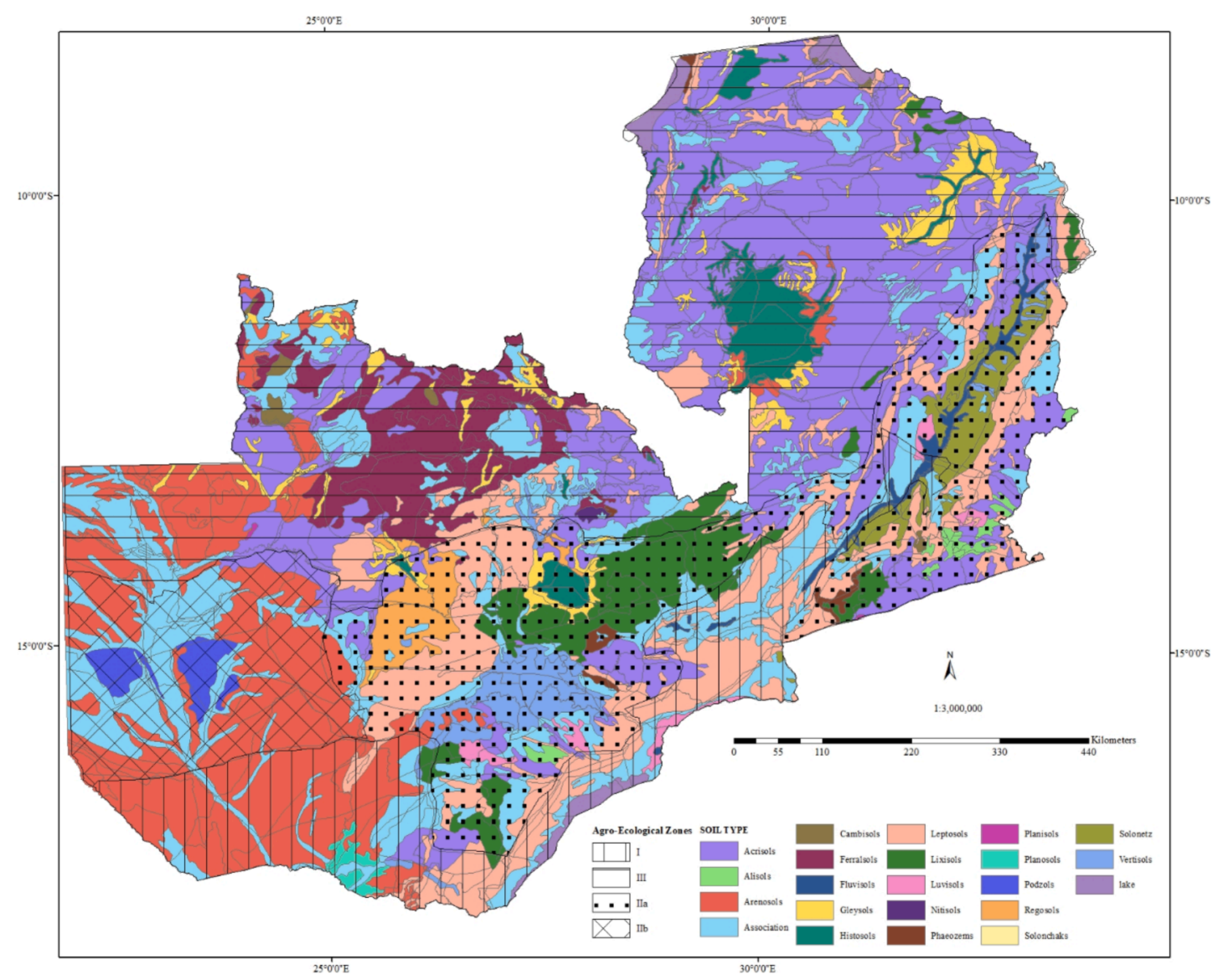

Fig. 2. Agro-ecological zones and Soils map of Zambia Author's illustration with data from (GRZ, 1991).

Table 2

Data, format and sources.

\begin{tabular}{|c|c|c|c|}
\hline Data & Format & Resolution & Source \\
\hline Topographic data (DEM) & Raster & $30 \times 30 \mathrm{~m}$ & $\begin{array}{l}\text { USGS (https://earthexplor } \\
\text { er.usgs.gov) }\end{array}$ \\
\hline $\begin{array}{l}\text { Climatic data (rainfall, } \\
\text { temperature) }\end{array}$ & Raster & $1 \times 1 \mathrm{~km}$ & $\begin{array}{l}\text { WorldClim (www.worldcl } \\
\text { im.org) }\end{array}$ \\
\hline Soil data (CEC, pH, SOC) & Raster & $\begin{array}{l}250 \times 250 \\
\mathrm{~m}\end{array}$ & $\begin{array}{l}\text { Soil Grids (https://soil } \\
\text { grids.org) }\end{array}$ \\
\hline
\end{tabular}

\subsubsection{Data analysis and processing}

The DEM was pre-processed. First pit and sink filling was performed on the DEM using the fill tool in spatial analyst tools of ArcMap 10.7.1. The DEM was then filtered using the filter tool in spatial analyst tools which employs a low pass filter using a $3 \times 3$ moving window to smooth the raster dataset. Slope was then calculated from the pre-processed DEM using the slope tool in ArcMap. The average values of soil properties (OC, CEC, $\mathrm{pH}$ and coarse fragments), over the depth interval 0-30 $\mathrm{cm}$, were obtained by a weighted average of the predictions using the numerical integration trapezoidal rule explained in detail by Hengl et al. (2017). The $0-30 \mathrm{~cm}$ soil layer can be agronomically considered as effective depth influencing plant root morphology and nutrient uptake for rice for which the planting depth is in the range of 3-5 cm (Drescher et al., 2020). All the datasets whose cell size was $<1 \mathrm{~km}$ where then rescaled to $1 \mathrm{~km}$ using the resampling tool in ArcGIS using the nearest neighbor function.

Once all the data on each SSF were acquired and processed, the suitability levels of each SSF were defined, based on the FAO land suitability classification as: Highly Suitable (S1), Moderately Suitable (S2), Marginally Suitable (S3), Currently Not Suitable (N2), and
Permanently Not Suitable (N1). Table 3 gives the interpretation of each FAO land suitability class.

Information from the published literature and crop production guides was used to define, for each SSF, a range of values corresponding to the five FAO suitability classes shown in Table 3 . The ranges are presented in Table 4. Most of the information is from Sys et al. (1993) who categorized requirements for various crops, including paddy rice, grown in tropical and sub-tropical regions into the FAO suitability classes and provided recommendations requirements regarding climate, soil condition and topography. The other sources are from studies in comparable environments. The SSF categories used in this study are therefore proposed as generally applicable for land suitability assessment for rice production in tropical and sub-tropical regions.

For purposes of further manipulation and display, the FAO suitability categories were reclassified to numerical scores, assigning values 1 ("Permanently not suitable"), 2 ("Not suitable"), 3 ("Marginally suitable"), 4 ("Moderately suitable") or 5 ("Highly suitable").

Table 3

Interpretation of the FAO land suitability class (FAO, 1976).

\begin{tabular}{ll}
\hline $\begin{array}{l}\text { FAO land suitability } \\
\text { class }\end{array}$ & Interpretation \\
\hline Class S1 & $\begin{array}{l}\text { Land with minor limitations to productivity. Not perfect but is } \\
\text { the best that can be hoped for } \\
\text { Land that is clearly suitable, but which has limitations that } \\
\text { either reduce productivity or increase the inputs needed to } \\
\text { sustain productivity compared with those needed on S1 land } \\
\text { Land with severe limitations that reduces benefits and/or } \\
\text { increase the inputs needed to sustain production so that this } \\
\text { cost is only marginally justified } \\
\text { Land is permanently not suitable for the given use usually } \\
\text { because of physical limitations. }\end{array}$ \\
\hline
\end{tabular}


Table 4

Land use requirements for rainfed paddy rice.

\begin{tabular}{|c|c|c|c|c|c|}
\hline Criterion & $\begin{array}{l}\text { Highly suitable } \\
\text { (S1) }\end{array}$ & $\begin{array}{l}\text { Moderately suitable } \\
\text { (S2) }\end{array}$ & $\begin{array}{l}\text { Marginally suitable } \\
\text { (S3) }\end{array}$ & Not suitable $(\mathrm{N})$ & Source \\
\hline Annual rainfall $(\mathrm{mm})$ & $>1400$ & $1200-1400$ & $1000-1200$ & $<1000$ & Sys et al. (1993) \\
\hline Annual mean temperature $\left({ }^{\circ} \mathrm{C}\right)$ & $31-24,31-36$ & $24-18,>36$ & 18-10, & $<10$ & Sys et al. (1993) \\
\hline Slope $(\%)$ & $0-1$ & $1-2$ & $2-3$ & $>3$ & $\begin{array}{l}\text { Masoud et al. (2013), Ojara et al. } \\
\text { (2017) }\end{array}$ \\
\hline $\begin{array}{l}\text { Coarse fragment (Volumetric } \% \text { of soil particles > } \\
2 \mathrm{~mm} \text { diameter) }\end{array}$ & $0-3$ & $3-15$ & $15-35$ & $>35$ & Sys et al. (1993) \\
\hline Drainage (FAO, 2006) & Imperfect, Poor & Moderate, Well & Somewhat excess & $\begin{array}{l}\text { Very poor, } \\
\text { Excessive }\end{array}$ & Sys et al. (1993) \\
\hline Soil pH $\left(\mathrm{H}_{2} \mathrm{O}\right)$ & $5.5-8.0$ & $8.0-8.5,5.0-5.5$ & $4.5-5.0$ & $>8.5,<4.5$ & Sys et al. (1993) \\
\hline $\mathrm{CEC}(\mathrm{cmol} / \mathrm{kg})$ & $>40$ & $25-40$ & $15-25$ & $<15$ & $\begin{array}{l}\text { Masoud et al. (2013), Ojara et al. } \\
\text { (2017) }\end{array}$ \\
\hline Soil organic carbon (\%) & $>1.5$ & $1.5-0.8$ & $<0.8$ & - & $\begin{array}{l}\text { Sys et al. (1993), Ambarwulan } \\
\text { et al. (2016) }\end{array}$ \\
\hline
\end{tabular}

The steps outlined above resulted in eight suitability maps, one for each SSF. These datasets needed to be combined and transformed into a single suitability output map. This is the key challenge of multicriteria evaluation. For simplicity we consider first an example case where just two factors, annual rainfall and slope, are used (Table 5). In a "dominated" situation (Table 5), it is easy to put together such information because site A is highly suitable with respect to both slope and rainfall and site $B$ is unsuitable by both criteria, therefore one can easily conclude that site A is highly suitable and site B is not suitable. But this is not generally the case. Consider a non-dominated case (Table 6) where A, is highly suitable in so far as this is judged by rainfall but is not suitable with respect to slope and site $B$ the converse applies with respect to both factors. In this case it becomes difficult to evaluate the suitability of each location for paddy rice production. To solve this challenge, we introduce weights of influence. In this approach an overall suitability score is computed which is a weighted linear combination of the scores for different factors. Each factor has a weight which reflects its overall importance in determining the overall suitability of any site. If the weights are constrained to sum to 1 then the resulting weighted combination of values will lie in the same interval as the constituent scores, 1 to 5 . It should be noted that this is not the only way in which different scoring systems could be combined in an overall assessment. The key assumption is that no one factor can be absolutely limiting on rice production, because if two or more factors have similar and appreciable weights then a deficiency in one might be substituted by the other being very suitable.

\subsubsection{Weighting of the factors}

The calculation of weights was based on expert elicitation. The process of elicitation that we used here is based on the method of Saaty (1988) which requires that the expert considers all pair-wise comparisons of factors, evaluating their relative importance according to a fixed scale. The first step involves creation of a pairwise matrix A which is $n \times$ $n$ where $n$ is the number of factors. There is $n(n-1) / 2$ unique comparisons between factors, represented by the elements of the matrix $a_{i j}$ where $i<j$. These values were taken from the scale due to Saaty (1988). These scores range from $1 / 9$ to 9 . If $a_{i j}$ is equal to 1 this implies that factors $i$ and $j$ are of equal importance; if $a_{i j}$ is equal to 9 this implies that factor $i$ dominates factor $j$ almost completely in any consideration of suitability of a site for rice. Conversely, if factor $j$ dominates factor $i$ almost completely, then $a_{i j}$ is equal to $1 / 9$. In Saaty's (1988) system intervening values of 3,5 and 7 are assigned if factor $i$ dominates factor $j$

Table 5

An example of a dominated case.

\begin{tabular}{llll}
\hline & Annual rainfall $(\mathrm{mm})$ & Slope $(\%)$ & Suitability \\
\hline Site A & 1400 (highly suitable) & $0-1$ (highly suitable) & Highly suitable \\
Site B & $<800$ (not suitable) & $>5$ (not suitable) & Not suitable \\
\hline
\end{tabular}

Table 6

An example of a non-dominated case.

\begin{tabular}{llll}
\hline & Annual rainfall $(\mathrm{mm})$ & Slope $(\%)$ & Suitability \\
\hline Site A & 1400 (highly suitable) & $>5$ (not suitable) & $?$ \\
Site B & $<800$ (not suitable) & $0-1$ (highly suitable) & $?$ \\
\hline
\end{tabular}

"moderately", "strongly" or "very strongly" respectively, and evennumbered scores can reflect uncertainty or compromise between experts whose opinions are elicited. As before, if factor $j$ dominates factor $i$ "moderately", "strongly" or "very strongly" then $a_{i j}$ is set to $1 / 3,1 / 5$ or $1 / 7$ respectively. Once all values $a_{i j}$ are obtained where $i<j$ the matrix may be completed according to the rule:

$$
\begin{aligned}
a_{j, i} & =\left\{a_{i, j}\right\}^{-1}, i \neq j \\
& =1, \quad i=j .
\end{aligned}
$$

Table 7 shows the comparison of factors in the rows (i) against those in the columns $(j)$. The scores in Table 7 were based either on published values from the application of this approach to land suitability evaluation in other studies, or local expert judgements made by the lead author in consultation with experts comprising extension staff from Ministry of Agriculture, researchers from Zambia Agricultural Research Institute (ZARI) and rice farmers. Table 8 shows the sources for each score in the pairwise matrix. Scores for the comparison of slope, temperature, $\mathrm{pH}$ and OC against each other were obtained from Ayoade (2017) who compared these factors against each by carrying out a quantitative analysis of the relationships between rice yield and environmental variables. Scores for $\mathrm{CEC} / \mathrm{pH}, \mathrm{pH} /$ drainage, $\mathrm{CEC} /$ drainage and slope/ coarse fragments were based on Moreno and Sánchez (2007), Dengiz et al., 2015, Yohannes and Soromessa (2018) and Massawe et al. (2019) respectively. Note that all but one of these sources (Dengiz et al. (2015), which reported on a study from Turkey and was consulted for the $\mathrm{pH} /$ drainage comparison) was from Tropical or Subtropical conditions. Overall, 16 out of the 28 pairwise comparisons between factors were based on local expert opinion. That means that our assessment most safely applies to Zambian conditions, where the experts were based and which they were explicitly considering.

A pairwise matrix produced in this way could be either consistent or inconsistent. For example, if in a set of consistent pair-wise comparisons, $\mathrm{x}$ is more important than $\mathrm{y}$ and $\mathrm{y}$ is more important than $\mathrm{z}$ then $\mathrm{x}$ must be more important than $\mathrm{z}$. There is no guarantee that a matrix A obtained by eliciting individual elements from experts will be consistent, and this must be evaluated before the matrix is used further. Saaty (1988) proved that if a pairwise matrix is consistent, then the maximum eigenvalue should be equal to the order of the matrix. The maximum eigenvalue of the pairwise matrix in Table 7 was then computed with the eigen function R platform (R Core Team, 2019).

The computed maximum eigenvalue $\left(\lambda_{\max }\right)$ of the matrix in Table 7 is 
Table 7

Pairwise comparison matrix (we compare the factors in the rows (i) against those in the columns (j)).

\begin{tabular}{|c|c|c|c|c|c|c|c|c|}
\hline \multirow[t]{2}{*}{ Criterion } & \multicolumn{8}{|c|}{ Pairwise comparison matrix } \\
\hline & Coarse fragment & Slope & Drainage & $\mathrm{pH}$ & Soil organic carbon & Cation exchange capacity & Mean annual temperature & Annual rainfal \\
\hline Coarse fragment & 1 & $1 / 2$ & $1 / 9$ & $1 / 5$ & $1 / 6$ & $1 / 9$ & 1 & 1 \\
\hline Slope & 2 & 1 & $1 / 5$ & $1 / 3$ & $1 / 5$ & $1 / 6$ & 2 & 2 \\
\hline Drainage & 9 & 5 & 1 & 7 & 4 & 1 & 9 & 9 \\
\hline $\mathrm{pH}$ & 5 & 3 & $1 / 7$ & 1 & $1 / 3$ & $1 / 7$ & 5 & 5 \\
\hline Soil organic carbon & 6 & 5 & $1 / 4$ & 3 & 1 & $1 / 4$ & 6 & 6 \\
\hline Cation exchange capacity & 9 & 6 & 1 & 7 & 4 & 1 & 9 & 9 \\
\hline Mean annual temperature & 1 & $1 / 2$ & $1 / 9$ & $1 / 5$ & $1 / 6$ & $1 / 9$ & 1 & 1 \\
\hline Annual rainfall & 1 & $1 / 2$ & $1 / 9$ & $1 / 5$ & $1 / 6$ & $1 / 9$ & 1 & 1 \\
\hline
\end{tabular}

Table 8

Sources for the scores of the pairwise matrix in Table 7.

\begin{tabular}{|c|c|c|c|c|c|c|c|c|}
\hline \multirow[t]{2}{*}{ Criterion } & \multicolumn{8}{|c|}{ Pairwise comparison matrix } \\
\hline & $\begin{array}{l}\text { Coarse } \\
\text { fragment }\end{array}$ & Slope & Drainage & $\mathrm{pH}$ & $\begin{array}{l}\text { Soil organic } \\
\text { carbon }\end{array}$ & $\begin{array}{l}\text { Cation } \\
\text { exchange } \\
\text { capacity }\end{array}$ & $\begin{array}{l}\text { Mean annual } \\
\text { temperature }\end{array}$ & $\begin{array}{l}\text { Annual } \\
\text { rainfal }\end{array}$ \\
\hline Coarse fragment & 1 & & & & & & & \\
\hline Slope & $\begin{array}{l}\text { Massawe et al. } \\
\text { (2019) }\end{array}$ & 1 & & & & & & \\
\hline Drainage & $\begin{array}{l}\text { Local expert } \\
\text { opinion }\end{array}$ & Local expert opinion & 1 & & & & & \\
\hline $\mathrm{pH}$ & $\begin{array}{l}\text { Local expert } \\
\text { opinion }\end{array}$ & $\begin{array}{l}\text { Ayoade (2017), } \\
\text { Yohannes and Soromessa } \\
\text { (2018) }\end{array}$ & $\begin{array}{l}\text { Dengiz et al. } \\
(2015)\end{array}$ & 1 & & & & \\
\hline $\begin{array}{l}\text { Soil organic } \\
\text { carbon }\end{array}$ & $\begin{array}{l}\text { Local expert } \\
\text { opinion }\end{array}$ & Ayoade (2017) & $\begin{array}{l}\text { Local expert } \\
\text { opinion }\end{array}$ & Ayoade (2017) & 1 & & & \\
\hline $\begin{array}{l}\text { Cation exchange } \\
\text { capacity }\end{array}$ & $\begin{array}{l}\text { Local expert } \\
\text { opinion }\end{array}$ & Local expert opinion & $\begin{array}{l}\text { Yohannes and } \\
\text { Soromessa (2018) }\end{array}$ & $\begin{array}{l}\text { Moreno and } \\
\text { Sánchez (2007) }\end{array}$ & $\begin{array}{l}\text { Local expert } \\
\text { opinion }\end{array}$ & 1 & & \\
\hline $\begin{array}{l}\text { Mean annual } \\
\text { temperature }\end{array}$ & $\begin{array}{l}\text { Local expert } \\
\text { opinion }\end{array}$ & Ayoade (2017) & $\begin{array}{l}\text { Local expert } \\
\text { opinion }\end{array}$ & Ayoade (2017) & $\begin{array}{l}\text { Ayoade } \\
(2017)\end{array}$ & & 1 & \\
\hline Annual Rainfall & $\begin{array}{l}\text { Local expert } \\
\text { opinion }\end{array}$ & Local expert opinion & $\begin{array}{l}\text { Local expert } \\
\text { opinion }\end{array}$ & $\begin{array}{l}\text { Local expert } \\
\text { opinion }\end{array}$ & $\begin{array}{l}\text { Local expert } \\
\text { opinion }\end{array}$ & $\begin{array}{l}\text { Local expert } \\
\text { opinion }\end{array}$ & $\begin{array}{l}\text { Local expert } \\
\text { opinion }\end{array}$ & 1 \\
\hline
\end{tabular}

8.46 which is larger than the order of the matrix (8). This indicates that there is some level of inconsistency in the pairwise matrix. However, Saaty (1988) recognized that, if one thinks of the elicited matrix A as an estimate of an underlying consistent matrix, $\AA$, with the estimate obtained with some observation error, then some small degree of inconsistency in $\mathbf{A}$ is likely and is practically tolerable. Saaty proposed that the consistency of $\mathbf{A}$ is measured by a consistency index $C I$, which is computed by

$C I=\frac{\lambda_{\max }-n}{n-1}$,

where $\lambda_{\max }$ is the maximum eigenvalue of $\mathbf{A}$ which is of order $n$. Saaty (1980) conducted computational experiments in which matrices of order 3-10 were generated by random selection of index values from 1 / 9 to 9 for elements $a_{i j}$ where $i<j$ with other elements obtained according to Eq. (1). For each matrix he computed CI and repeated these 500 times. Table 9 shows the mean values of CI for matrices of order 3-10, which Saaty called the Random Index (RI). As a rule of thumb Saaty proposed a consistency ratio, $\mathrm{CR}$, which is the ratio of $\mathrm{CI}$ for an elicited matrix $\mathrm{A}$ to the tabulated value of RI for random matrices of the same order. He suggested that the matrix may be used if $\mathrm{CR}$ is $<0.1$.

In this case:

Table 9

Tabulated for random matrices (RI).

\begin{tabular}{lllllllll}
\hline Order matrix $(n)$ & 3 & 4 & 5 & 6 & 7 & 8 & 9 & 10 \\
\hline Random index & 0.58 & 0.9 & 0.12 & 1.24 & 1.32 & 1.41 & 1.45 & 1.49 \\
\hline
\end{tabular}

Source: Golden and Wang (1990).
$C I=\frac{\lambda_{\max }-n}{n-1}=\frac{8.46-8}{8-1}=0.066$

$C R=\frac{C I}{R I}=\frac{0.066}{1.41}=0.047<0.1$.

This shows that the comparison matrix presented in Table 6 is acceptable for further use.

The pairwise comparison matrix A (Table 7) was then normalized by dividing each element $\left(a_{i j}\right)$ by the corresponding column sum (Eq. (5)). The elements of the normalized comparison matrix, $\mathbf{B}$, are therefore

$b_{i j}=\frac{a_{i j}}{\sum_{i=1}^{n} a_{i j}}$

Then to obtain the weight of each criterion $\left(w_{i}\right)$ the row sum of the normalized matrix was then divided by the matrix order $n$ (Eq. (6)) and the sum of the criteria weights must equal to one. Table 10 shows the weights of each criteria.

$w_{i}=\left(\frac{1}{n}\right) \sum_{j=1}^{n} b_{i j}$

\subsubsection{Weighted overlay}

Once the raster files had been reclassified to a common measurement scale and the weights of influence for each criterion determined, a weighted overlay was performed in ArcMap for all the reclassified criteria raster files. This overlay tool used tool combines several raster files to one by first multiplying cell values in each raster by the raster weight of influence and then adds the results to create a single output map. The final values of the output raster are rounded up to whole numbers because the weighted overlay is integer, therefore giving an 
Table 10

Criteria weights and the ranking.

\begin{tabular}{|c|c|c|c|c|c|c|c|c|}
\hline Criterion & Coarse fragment & Slope & Drainage & $\mathrm{pH}$ & Soil organic carbon & Cation exchange capacity & Mean annual temperature & Annual rainfall \\
\hline Weight & 0.027 & 0.048 & 0.31 & 0.096 & 0.149 & 0.316 & 0.027 & 0.027 \\
\hline
\end{tabular}

output raster with the same common sale as that of the input raster.

\subsection{Statistical evaluation of the suitability map}

Locations for households growing different crops including rice were obtained from the Rural Agricultural Livelihoods Survey (RALS) of 2012 data collected by Indaba Agricultural Policy Research Institute (IAPRI) in collaboration with Central Statistical Office (CSO) and Ministry of Agriculture. RALS is a nationally representative panel survey designed to obtain a comprehensive picture of Zambia's small and medium-scale farming sector using the 2010 census sampling frame. The data obtained through this survey is unique because it is georeferenced. The sampling frame for the RALS 2012 survey was based on the 2010 Census of Housing and Population, CSO/MAL/IAPRI (2015). A stratified two-stage sample design (CSO, 2012) was used (see Appendix A for details). The RALS 2012 covered 442 Standard Enumeration Areas (SEAs) across the 10 provinces and a total of 8840 households (CSO/MAL/IAPRI, 2015). Fig. 3 shows the SEA locations for RALS 2012.

The extent to which the distribution of rice producers from the three categories is related to suitability was examined in contingency tables and data from the RALS 2012 survey was used for this analysis. Data cleaning involved removal of spurious values in the $\mathrm{x}$ and $\mathrm{y}$ coordinates. The need for this was indicated when the raw data were first plotted, showing points lying outside the borders of Zambia. The mean coordinates of all households were computed in each SEA (SEA centroid), and then the households were removed from the data set if the notional distance to the SEA centroid exceeded $10 \mathrm{~km}$. After data cleaning, a total of 7823 households were used to test the null hypothesis that the presence and absence of rice at a sample site and the rice suitability index are independently distributed. Because this evaluation is for paddy rice, only those households that planted local varieties were considered in the presence category. Those that planted improved varieties were put in absence category as it is very likely that some of the improved varieties are upland rice.

Contingency tables were obtained which show the distribution of

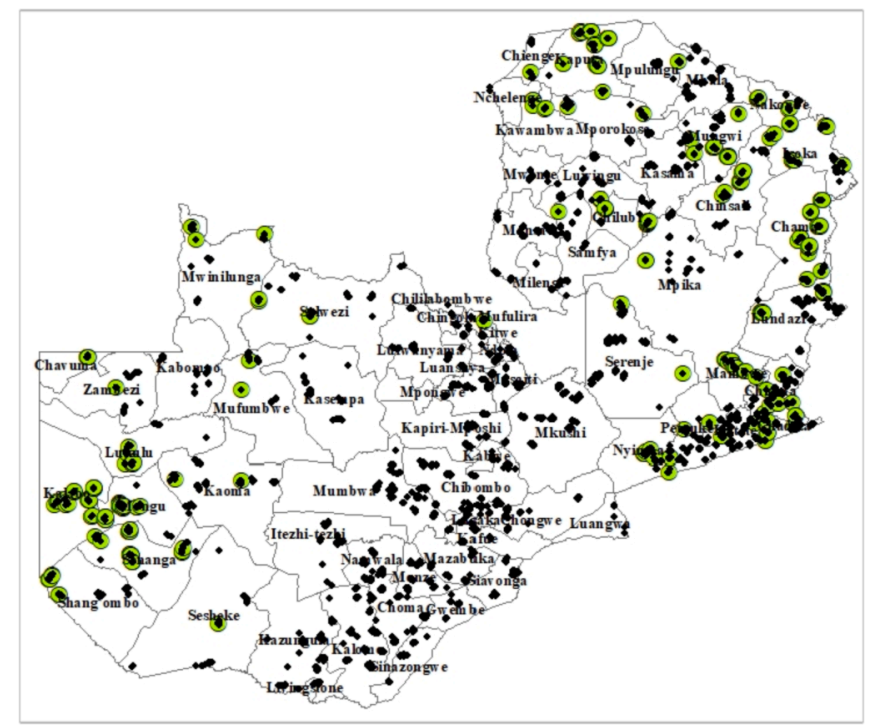

Fig. 3. Standard Enumeration Area (SEA) locations for the RALS 2012 survey. The points in black are for all SEAs and the ones with the light green circle are the locations with rice present. observations between Suitability Class (columns) and Crop Presence (rows: rice present or absent). These were then analyzed with the chisq. test function of the package stats for the R platform (R Core Team, 2019), This was done separately for farms in the three categories. The test statistic, $X^{2}$, is the sum over all cells of the squared difference between the observed number of households and the expected number under a null hypothesis of random association, the squared difference being divided by the expected value. Under the null hypothesis, which is of random association between crop presence and suitability, the expected number of households in any cell is equal to the product of the corresponding row and column totals divided by the total number of observations in the table. If the null hypothesis is true, then the $X^{2}$ statistic is distributed as $\chi^{2}$ with degrees of freedom equal to $\left(n_{\mathrm{r}}-1\right) \times\left(n_{\mathrm{c}}\right.$ -1 ) where $n_{\mathrm{r}}$ and $n_{\mathrm{c}}$ are respectively the number of rows and columns in the contingency table. We interpret the results of this analysis as follows. If the null hypothesis is accepted, then we have no evidence that there is any association between the suitability of land for rice production on one hand, and the presence or absence of a rice crop in the other. However, if the suitability index is informative, then we would expect to find a larger proportion of sites where rice is grown where the suitability index is large than where it is small. This is despite the fact that rice might be grown, for cultural or economic reasons, at some unsuitable sites, and similarly might not be grown at some sites where it is suitable. Thus, if the null hypothesis can be rejected, and there are more sites with rice grown in the classes with larger suitability than expected under the null hypothesis, then this is evidence that the suitability index is, indeed, informative.

\section{Results}

\subsection{Suitability levels of each criterion}

Fig. 4 shows the reclassified maps of suitability levels of each criterion and Fig. 5 shows the proportions of each suitability classes for each criterion. At least $90 \%$ of the study area has CEC that is not suitable with most of the country having CEC ranging between 5 and $15 \mathrm{cmol} / \mathrm{kg}$ which is currently not suitable and part of the western part having CEC $<5 \mathrm{cmol} / \mathrm{kg}$ which is permanently not suitable. Despite having highly
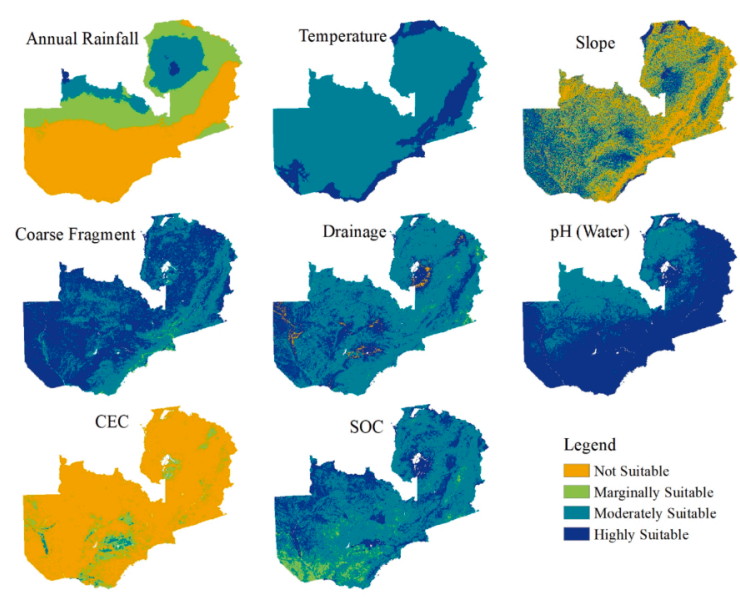

Legend

Not Suitable

Marginally Suitable

Moderately Sutable

Fig. 4. Suitability classes for each criterion. 


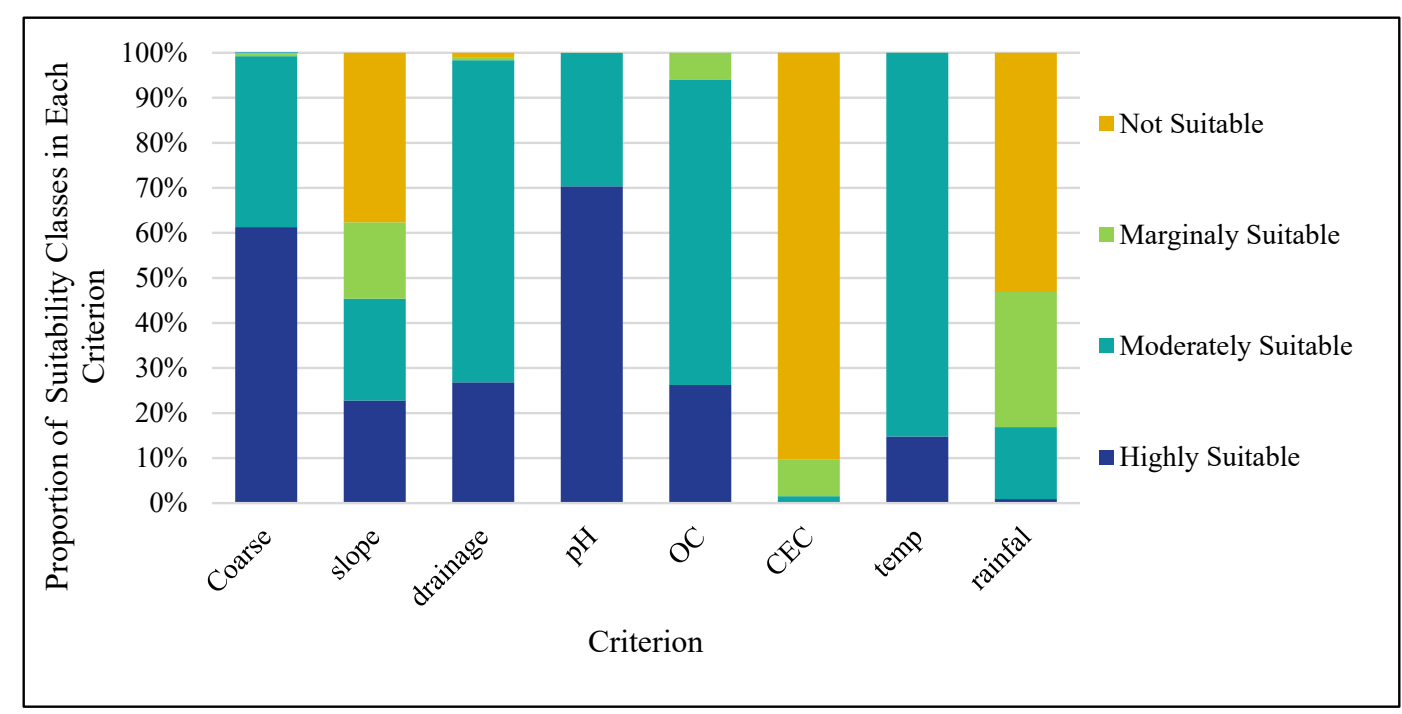

Fig. 5. Proportions of suitability classes in each suitability criterion.

suitable temperature and $\mathrm{pH}$, the Eastern and Southern part of the country have slope of $>5 \%$ which is permanently not suitable for paddy rice production. The Southern part of the study area also is affected by low rainfall which is $<800 \mathrm{~mm}$ permanently not suitable and the middle part of the country having rainfall between 800 and $1000 \mathrm{~mm}$ currently not suitable. In areas such as eastern and southern parts with one criterion highly suitable and another not suitable, it becomes difficult to evaluate the suitability levels, hence the introduction of weights of influence for each criterion which were used to produce the final suitability map.

In their study on Soyabean suitability in Kabwe District of Zambia, Munene et al. (2017) also observed some limitations owing to soil pH, low SOC and slope. Chirwa et al. (2016) evaluated the soil fertility status and land suitability for smallholder farmers' groundnut and maize production in Chisamba District of Zambia and concluded that soil $\mathrm{pH}$, low CEC were some of the major soil fertility limiting factors.

\subsection{Suitability of rainfed paddy rice in Zambia}

Fig. 6 is the rainfed paddy rice suitability map of Zambia produced

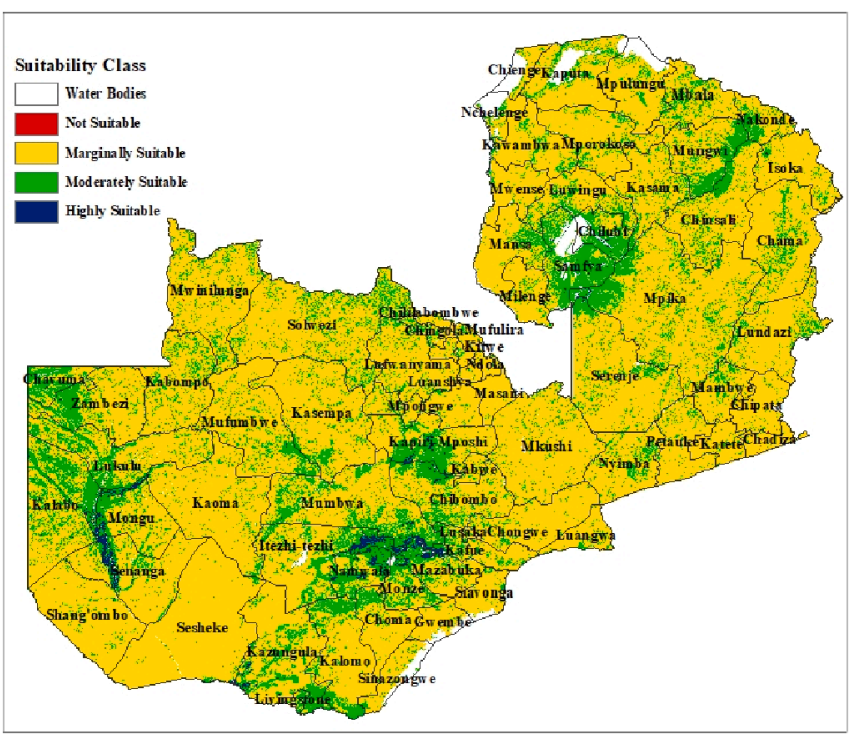

Fig. 6. Suitability map for rainfed paddy rice in Zambia. using weighted overlay of the eight suitability criterion maps. Fig. 7 shows that some of the suitable areas are not available for production as they fall under urban, national parks and forest reserves. Fig. 8 shows the area proportions of suitability classes for total area, area under urban, area under national parks, area under forest reserves and potential area (this is the area available for agriculture production when we subtract that covered by national parks, forest reserve and urban as these are not available for agriculture production). And it can be observed that when we take into consideration the areas under national parks, water bodies and forest reserves, $<1 \%$ of the potential area is highly suitable, while $19 \%$ is moderately suitable, $80 \%$ marginally suitable and $<1 \%$ is not suitable. Fig. 9 shows that landcover map of Zambia (ESA, 2017).

\subsection{Validation of the suitability map}

Tables 11-13 show the observed and expected counts for each cell of the crop presence and suitability class contingency tables for households in category A, B and C respectively. Also shown are the $X^{2}$ statistic and associated $p$-value under the null hypothesis of random association. For households in category A and B the value of the statistic, is large, and the

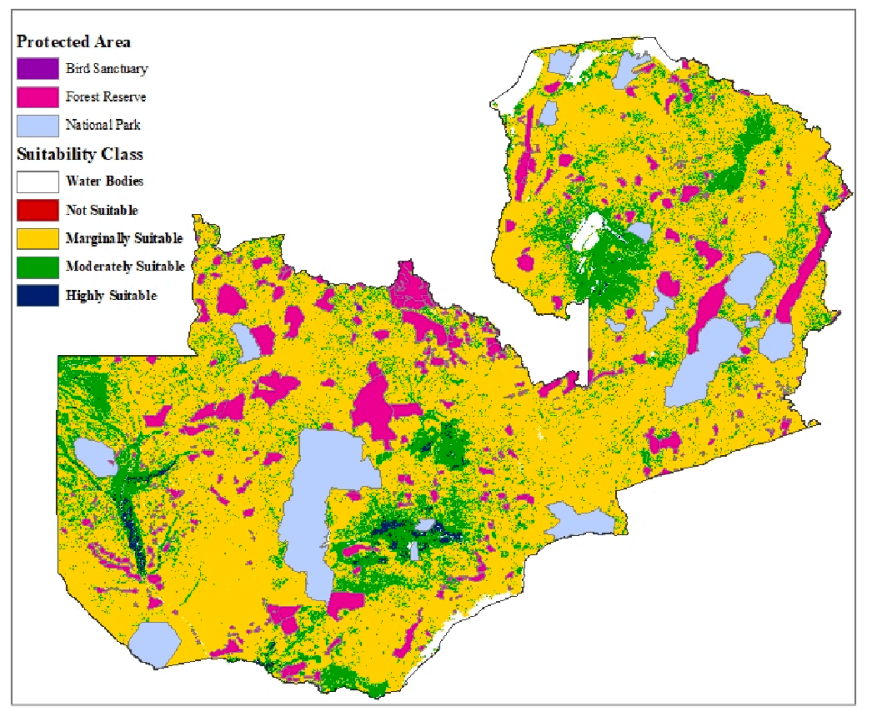

Fig. 7. Protected area over the suitability map of rainfed paddy rice in Zambia. 


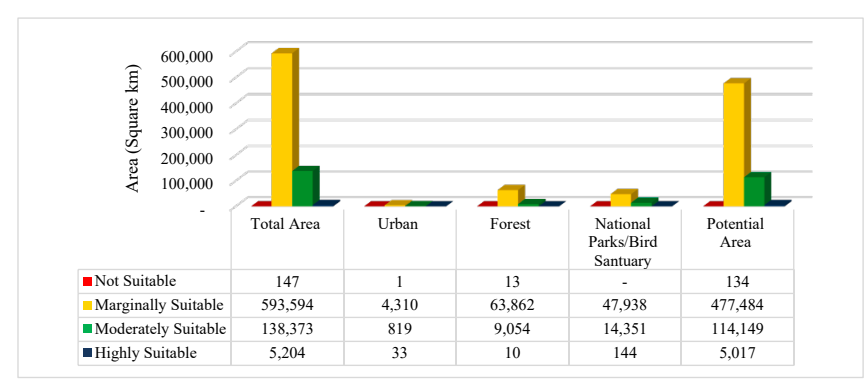

Fig. 8. Area Proportion of Suitability classes.

probability of a value this large or larger under the null hypothesis is small ( $p=0.0002$ for category A and $p=0.0004$ for category B). This is evidence to reject the null hypothesis. This is not the case for Category $\mathrm{C}$ $(p=0.31)$, so the null hypothesis is retained in this case. For both category A and B, it is observed that there are fewer households with rice present observed than expected under the null hypothesis in the marginally suitable class, and more in the moderately suitable class. This is consistent with the suitability classes' being informative about land suitability for rice production.

\section{Discussion}

The method used to obtain weights to combine the different factors was based on a pair-wise rating method, tested for consistency. However, it reveals an underlying hierarchical structure of these factors in terms of their implied importance as suitability determinants for rice production. The factors, shown in Table 6, can be divided in three categories. First are the climate factors (Rainfall and Temperature; second are the topographic and soil physical factors (coarse fragment, drainage and slope) and finally, soil chemical factors ( $\mathrm{pH}, \mathrm{OC}$ and CEC). And as shown by the weights in Table 10 three things can be observed. First, coarse fragment, temperature and rainfall have the lowest weights of 0.027 and are dominated by soil physical and chemical factors with higher weights. Second, Drainage has a higher weight of 0.031 dominating all soil physical factors and chemical factors except for CEC whose weight is 0.0326 . Third, CEC dominates all other soil chemical properties, and all soil chemical properties dominate all other factors except for drainage which is equally important as CEC. In rice production, water availability is extremely important and it is determined by rainfall and soil water-holding capacity (Moormann and Van Breemen, 1978) it therefore unsurprising to see factors that reflect soil water holding capacity such such as Drainage and organic matter dominate other factors. Rainfall has a small weight, however, indicating that in the original judgment the capacity of the soil to retain water was regarded as

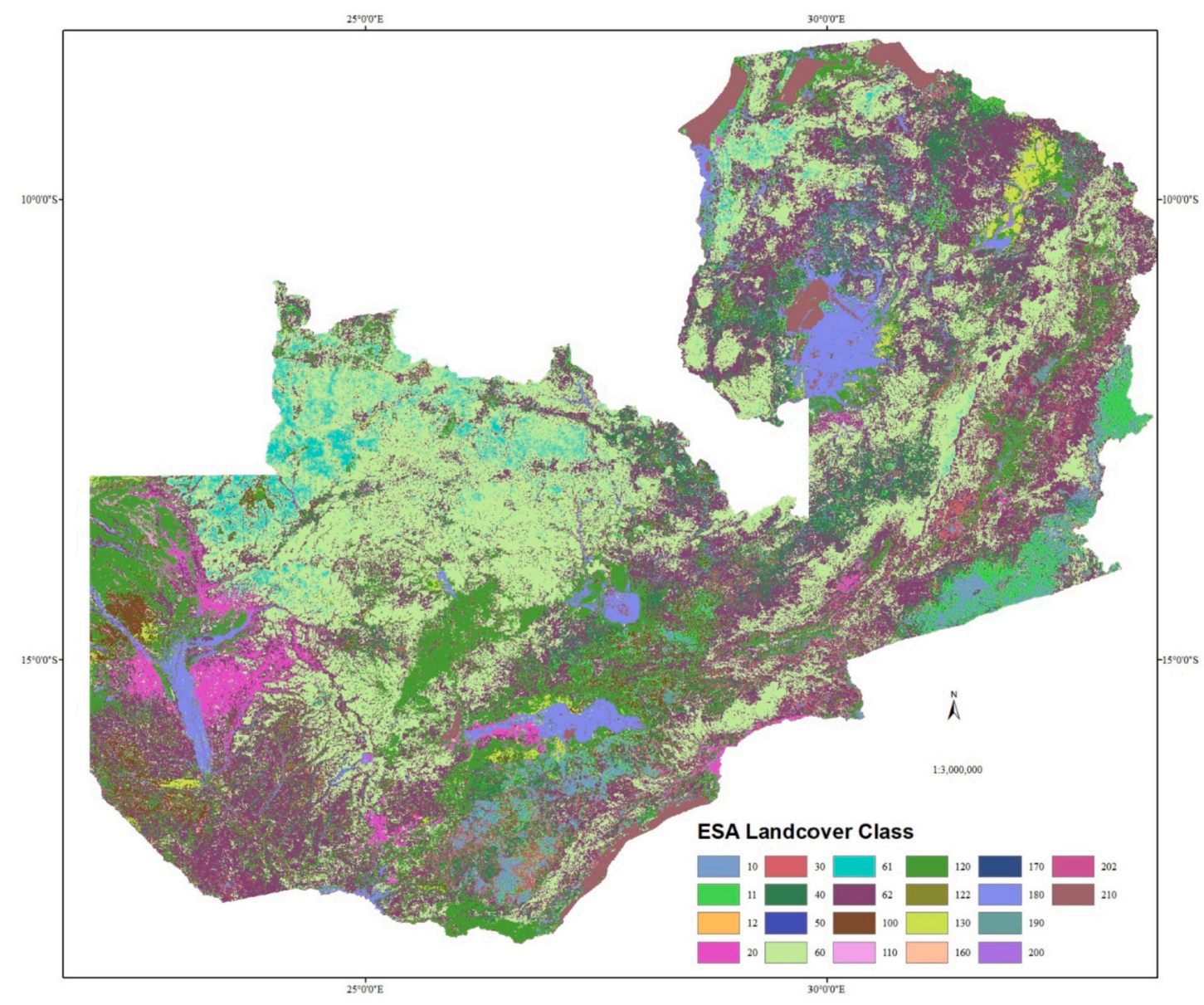

Fig. 9. ESA land cover map, $\mathbf{1 0}=$ rainfed cropland; $\mathbf{1 1}=$ Herbaceous cover; $\mathbf{1 2}=$ Tree or shrub cover; $\mathbf{2 0}=$ irrigated or post-flooding cropland; $\mathbf{3 0}=$ Mosaic cropland $(>50 \%) /$ natural vegetation (tree); $\mathbf{4 0}=$ herbaceous cover) $(>50 \%) /$ cropland $(<50 \%) ; \mathbf{5 0}=$ closed to open $(>15 \%)$, evergreen, broadleaved, tree cover; 60 closed to open $(>15 \%)$, deciduous, broadleaved, tree cover; $61=$ closed $(>40 \%)$, deciduous, broadleaved, tree cover; $62=$ open $(15-40 \%)$, deciduous, broadleaved, tree cover; $\mathbf{1 0 0}=$ Mosaic tree and shrub $(>50 \%) /$ herbaceous cover $(<50 \%) ; \mathbf{1 1 0}=$ Mosaic herbaceous cover $(>50 \%) /$ tree and shrub $(<50 \%) ; \mathbf{1 2 0}=$ Shrubland; $\mathbf{1 2 2}=$ Shrubland deciduous; $\mathbf{1 3 0}=$ Grassland; $\mathbf{1 6 0}=$ fresh or brackish water, flooded, tree cover; $\mathbf{1 7 0}=$ saline water, flooded, tree cover; $\mathbf{1 8 0}=$ fresh/ saline/brackish water, flooded Shrub or herbaceous cover; $190=$ Urban areas; $\mathbf{2 0 0}=$ Consolidated bare areas; $202=$ Unconsolidated bare areas; $\mathbf{2 1 0}=$ Water Bodies. Author's illustration with raster data from European Space Agency (ESA) (2017). 
Table 11

Table of observed, expected, deviation, chi-square and $p$ values from independence for rice farmers in category A(Agricultural households with 0-1.99 ha of land under crop or owing livestock $<50$ cattle, $<20$ pigs, $<30$ goats and or $<50$ chickens) and suitability classes.

\begin{tabular}{|c|c|c|c|c|c|}
\hline & & & \multicolumn{2}{|c|}{ Suitability class } & \\
\hline & & & $\begin{array}{l}\text { Moderately } \\
\text { suitable }\end{array}$ & $\begin{array}{l}\text { Marginally } \\
\text { suitable }\end{array}$ & \\
\hline \multirow{8}{*}{$\begin{array}{l}\text { Crop } \\
\text { presence }\end{array}$} & Rice & Observed & 62 & 121 & 183 \\
\hline & & Expected & 28.63 & 154.37 & \\
\hline & & $\mathrm{O}-\mathrm{E}$ & 33.37 & -33.37 & \\
\hline & No & Observed & 429 & 2526 & 2955 \\
\hline & rice & Expected & 462.37 & 2492.63 & \\
\hline & & O-E & -33.37 & 33.37 & \\
\hline & & & 491 & 2647 & 3138 \\
\hline & & \multicolumn{2}{|c|}{$X^{2}=48.947$} & \multicolumn{2}{|c|}{$p$-value $=0.0002$} \\
\hline
\end{tabular}

more important than absolute input.

The eight suitability maps for separate factors, showed that much land is not suitable or marginally suitable for paddy rice production as judged from CEC, rainfall and slope. The CEC of soil is restrictive mainly observed in the western part of the country, where soils formed in Kalahari sand cover have limited clay content. Large slopes were mainly observed in the eastern part of the country along the margins of valley areas. Low rainfall was observed mainly in southern parts of the country and irrigation could be one of the interventions for this limitation. Although we used rainfall data up to 2000, longer term analysis of climatic records up to 2012 showed that precipitation was variable from year to year while temperature had an increasing trend (Chabala et al., 2013; Stern and Cooper, 2011). The high variability indicates that when climate is considered alone, paddy rice production is unpredictable and can be associated with inconsistent crop growth and corresponding yield losses due to water stress especially amidst increasing temperatures. These contrasting patterns of limitations highlight the need for a suitable multicriterion basis for combining them into an overall assessment.

Based on the weighted factors, the overall suitability map showed that about $20 \%$ of the study area is highly and moderately suitable with highly suitable areas being in Western Province (west of Senanga and Mongu districts), some parts of Kafue flats (around the boarder of Namwala, Mumbwa, Itezhi-tezhi, Kafue, Mazabuka and Monze districts) and Central Province (border of Chibombo and Kapiri districts) and moderately suitable areas are in western parts of Western and NorthWestern Provinces (some parts of Chavuma, Zambezi, Lukulu, Kalabo, Mongu and Senanga districts), Central Province (some parts of Serenje, Kapiri-mposhi, Chibombo and Mumbwa districts), Southern part of Luapula Province (Mansa and Sanfya districts), southern and North eastern parts of Northern Province, north-western parts of Muchinga province and parts of Eastern Province.

With only about $20 \%$ of land area potentially suitable for paddy rice production, and taking into consideration competition with other staple crops, there is limited potential for rainfed paddy rice production in Zambia. Most of the land has limitations which are severe for production of rainfed paddy rice and will reduce productivity as well as increasing requirements for inputs. Therefore, it is necessary to explore the potential of irrigation and upland rice production in Zambia as this would help expand the production of rice beyond the limited potential suitable area for rainfed paddy rice. This result agrees with Mutale et al. (2010) whose study recommended that the New Rice for Africa (NERICA) upland varieties be explored for possible cultivation in upland Zambia. With such limited potential, there is also a need to improve the productivity of rainfed paddy rice among the few farmers growing the crop by investing resources in training them in agricultural practices that will help reduce the limitations such as increasing organic matter content of their fields by adding manure and practicing conservation agriculture as this will help increase the CEC as well as soil moisture retention of their soils.

The validation of the suitability map using RALS 2012 data showed that, among farmers in category $\mathrm{A}$ and $\mathrm{B}$, there were fewer rice presence than expected under random association in the marginally suitable class and more in the moderately suitable class, and that the difference between the observed numbers and expected numbers under random association was statistically significant $(p=0.0002$ and 0.0004 respectively) meaning there is a greater chance of rice being grown on moderately suitable land than would be expected by chance alone. However, the result for farmers in category $C$ was not statistically significant $(p=0.313$ ). This might be because smaller producers have less scope to adapt to constraints on land suitability (e.g. by applying manure).

This land suitability assessment was carried out entirely as a secondary data analysis using free access secondary data available on soilgrid, worldclim and USGS websites. Because surveys are costly and time consuming, such data can used to adress important problems without incurring the high cost and time consuming of a new survey.

As noted in the methods section, the division of the ranges of values for the SSF were based on a range of studies from across Tropical and Subtropical conditions. They may therefore be used in comparable

Table 13

Table of observed, expected, deviation, chi-square and $p$ values from independence for rice farmers in category C(agricultural households with 5-19.99 ha of land under crops, grown one or more special crops, raising $\geq 50$ cattle, $\geq 20$ pigs, $\geq 30$ goats and or $\geq 50$ chickens) and suitability classes.

\begin{tabular}{|c|c|c|c|c|c|}
\hline & & & \multicolumn{3}{|c|}{ Suitability class } \\
\hline & & & $\begin{array}{l}\text { Moderately } \\
\text { suitable }\end{array}$ & $\begin{array}{l}\text { Marginally } \\
\text { suitable }\end{array}$ & \\
\hline \multirow{8}{*}{$\begin{array}{l}\text { Crop } \\
\text { presence }\end{array}$} & Rice & Observed & 24 & 97 & 121 \\
\hline & & Expected & 19.55 & 101.45 & \\
\hline & & $\mathrm{O}-\mathrm{E}$ & 4.45 & -4.45 & \\
\hline & No & Observed & 272 & 1439 & 1711 \\
\hline & rice & Expected & 276.45 & 1434.55 & \\
\hline & & $\mathrm{O}-\mathrm{E}$ & -4.45 & 4.45 & \\
\hline & & \multirow{2}{*}{\multicolumn{2}{|c|}{$\mathrm{X}^{2}=1.2934$}} & 1536 & 1832 \\
\hline & & & & \multicolumn{2}{|c|}{$p$-value $=0.3131$} \\
\hline
\end{tabular}

Table 12

Table of observed, expected, deviation, chi-square and $p$ values from independence for rice farmers in category B(agricultural households with 2-4.99 ha area under crop) and suitability classes.

\begin{tabular}{|c|c|c|c|c|c|c|}
\hline & & & \multicolumn{3}{|l|}{ Suitability class } & \\
\hline & & & Moderately suitable & Marginally suitable & Not suitable & \\
\hline \multirow[t]{8}{*}{ Crop presence } & Rice & Observed & 47 & 144 & 0 & 191 \\
\hline & & Expected & 26.93 & 164 & 0.07 & \\
\hline & & $\mathrm{O}-\mathrm{E}$ & 20.07 & -20 & -0.07 & \\
\hline & No rice & Observed & 318 & 2079 & 1 & 2398 \\
\hline & & Expected & 338.07 & 2059 & 0.93 & \\
\hline & & $\mathrm{O}-\mathrm{E}$ & -20.07 & 20 & 0.07 & \\
\hline & & & 365 & 2223 & 1 & 2589 \\
\hline & & & \multicolumn{2}{|c|}{$X^{2}=18.867$} & \multicolumn{2}{|c|}{$p$-value $=0.003999$} \\
\hline
\end{tabular}


evaluations in other settings in the Tropics or Subtropics, although they should be updated whereever possible from the results of new studies or systematic reviews. However, the pairwise comparison matrix, A, was based primarily on local expert opinion. The validation results give some evidence that this opinion was soundly-based. However, the elicited pairwise matrix produced here should not be applied outside Zambia without care, and local experts should first be asked to review the comparisons made in Table 7 , and to amend these in the light of local experience. The methods section provides sufficient information on how the consistency of an amended matrix can be tested.

As we observed above, this land suitability assessment is based on expert judgment, and also on the assumption that overall land suitability can be treated as a weighted linear combination of contributions from multiple factors. The validation described above suggests that this assessment is of value, at least as a provisional guide, but further work is needed to develop such assessments and to refine them. These might use process models, or surveys of actual paddy rice yields at locations across Zambia or an analysis of proxy variables for crop yield, e.g. from remote sensor data, both to compare these between the suitability classes obtained here, but also to explore other non-linear effects of multiple factors, possibly using a modelling method such as boundary line analysis (Lark et al., 2020). Furthermore, this study has considered biophysical factors which might control land suitability, but farmers' decisions are not based only on biophysical limitations (Rossiter, 1995). We propose, however, that given the need to make assumptions about the joint effects of multiple factors, there is an argument for not combining biophysical and socio-economic factors into a single multicriterion index of suitability. We propose, for further research, that economic surveys are undertaken to record local commodity prices (rice and alternatives), input and labour costs, historical experience of rice production, contemporary attitudes to rice as a crop, knowledge of rice production among local extension officers. These could be focussed on areas where the analysis presented here suggests that biophysical factors are conducive to the production of paddy rice, but where the RALS data show marked differences in the extent to which local farmers choose to produce the crop. This would allow us to identify the key socioeconomic factors that may limit rice production where the physical environment is suitable for it.

\section{Conclusion}

To conclude, available secondary data can be used to carry out suitability assessment for not only rainfed paddy rice production but other crops as well. The suitability for rainfed paddy rice production was found and areas that are highly and moderately suitable identified. More than $80 \%$ of the country was found to be marginally and not suitable. Overall, the results indicate that with only $<20 \%$ of the country being highly and moderately suitable for rainfed paddy rice, there is limited potential to develop production in Zambia. These findings have implications for the National Rice Development Strategy (NRDS) of Zambia, which should also explore the potential of irrigation and of upland rice production in Zambia as this would help expand the potential production area of rice.

A review of the literature showed that there are few studies on land suitability assessment in Zambia, leaving the researchers to only use information from Sys et al. (1993) whose suitability class limits were based on experience from few countries. It is in this regard that we recommend that local expertise need to evaluate and alter these suitability classes.

\section{Declaration of Competing Interest}

The authors declare that they have no known competing financial interests or personal relationships that could have appeared to influence the work reported in this paper.

\section{Acknowledgements}

This study was made possible with support from the Zambian Ministry of Higher Education through their 2016/2017 science and technology female postgraduate scholarships. Funding from the Global Environment Facility (GEF) and support of the United Nations Industrial Development Organization (UNIDO) as a part of the Integrated Solutions for Water, Energy, and Land (ISWEL) project (GEF Contract Agreement: 6993) implemented by the International Institute for Applied Systems Analysis. The Commonwealth Scholarships Commission through their split-site scholarship. We also thank Indaba Agricultural Policy Research Institute (IAPRI) for allowing us to use their RALS 2012 survey data.

\section{Appendix A. Detailed RALS 2012 sampling procedure}

The first stage involved identifying the Primary Sampling Unit (PSU) which is one or more Standard Enumeration Areas (SEAs) each comprising a minimum of 30 agricultural households. The SEA is the smallest area with well-defined boundaries identified on census sketch maps. The second stage involved listing and identification of agricultural households in selected SEAs. The listed agricultural households were then stratified into three categories A, B and C (CSO/MAL/IAPRI, 2015). Category C comprised households with 5-19.99 ha of land under crops, grown one or more special crops, raising $\geq 50$ cattle, $\geq 20$ pigs, $\geq 30$ goats and or $\geq 50$ chickens. Category B comprised agricultural households with $2-4.99$ ha area under crop and category A comprised households with $0-1.99$ ha of land under crop or owing livestock numbers less than those specified in category C.

Systematic sampling from the household list comprised by the enumerators in the SEA was then used to select 20 households distributed across the three strata. Where all the three categories had adequate numbers of households listed, the sample household distribution was $C$ $=10, \mathrm{~B}=5$ and $\mathrm{A}=5$. Where there were shortfalls in category $\mathrm{C}$, all households in this category where selected and the difference from 20 was equally allocated to categories B and A. If the difference from 20 could not be equally allocated to the two categories, category B was allocated one more sample household than category A. Where there was no household in category C, 10 sample households were allocated to category B, and 10 to category A. Where there was no household in category $\mathrm{C}$ and $<10$ in category $\mathrm{B}$, all were included in the sample and the allocation for category A was increased to make up for the shortfall from the required number of 20 sample households. Where all households fall in category A, all the required 20 sample households were selected from that category. For each stratum, systematic sampling was done to select the required housed holds. First the sampling interval was calculated by dividing the total number of households in the category by the sample number. Then the random start number was selected by randomly selecting a column from the table of random numbers. Starting from the top of that column, the first random number between 1 and the number of households in category the category was selected, inclusive as the first corresponding selected household in the sample. To add the next household number, the sampling interval was added to the chosen random number and this procedure was repeated to add remaining households of the sample (CSO, 2012).

\section{Appendix A. Supplementary data}

Supplementary data to this article can be found online at https://doi. org/10.1016/j.geodrs.2021.e00438.

\section{References}

Agidew, A.A., 2015. Land suitability evaluation for sorghum and barley crops in South Wollo Zone of Ethiopia. J. Econ. Sustain. Dev. 6 (1), 14-25. https://pdfs.semanticsch olar.org/2b22/6926534e429fb599b7627317dcaee9463a0d.pdf.

Ambarwulan, W., Santoso, P.B., Sabiham, S., Hikmat, M., 2016. Remote sensing and land suitability analysis to establish local specific inputs for paddy fields in Subang, West 
Java. Procedia Environ. Sci. 33, 94-107. https://doi.org/10.1016/j. proenv.2016.03.061.

Aune, J.B., Sekhar, N.U., Esser, K., Tesfai, M., 2014. Opportunities for Support to System of Rice Intensification in Tanzania, Zambia and Malawi Opportunities for Support to System of Rice (No. 71). Department of International Environment; Development Studies, Noragric Faculty of Social Sciences, Norwegian University of Life Sciences.

Ayoade, M.A., 2017. Suitability assessment and mapping of Oyo State, Nigeria, for rice cultivation using GIS. Theor. Appl. Climatol. 129 (3-4), 1341-1354. https://doi.org/ 10.1007/s00704-016-1852-4.

Central Statistical Office (CSO), 2012. Rural Agricultural Livelihoods Survey; Instruction Manual for Listing, Sample Selection, and Largest Maize Field Data Collection. https://www.zamstats.gov.zm.

Central Statistical Office (CSO), 2018. Crop Forecast Survey 2017/18. https://www.za mstats.gov.zm.

Central Statistical Office, Ministry of Agriculture and Livestock, and Indaba Agricultural Policy Research Institute (CSO/MAL/IAPRI), 2015. Rural Agricultural Livelihoods Survey. CSO/MAL/IAPRI, Lusaka, Zambia.

Chabala, L.M., Kuntashula, E., Kaluba, P., 2013. Characterization of temporal changes in rainfall, temperature, flooding hazard and dry spells over Zambia. Univ. J. Agric. Res. 1 (4), 134-144.

Chirwa, M., Mrema, J.P., Mtakwa, P.W., Kaaya, A.K., Lungu, O.I., 2016. Evaluation of soil fertility status and land suitability for smallholder farmers' groundnut and maize production in Chisamba District, Zambia. Inte. J. Plant Soil Sci. 10 (4), 1-18. https:// doi.org/10.9734/IJPSS/2016/25161.

Chisci, G., 2009. Rice (Oryza sativa L.). In: Manual of Methods for Soil and Land Evaluation. CRC Press, pp. 197-202.

Chizhuka, F., 2009. A Study of the Rice Value-Chain in Zambia. CUTS Africa Resource Centre, Lusaka, Zambia.

De Data, S.K., 1981. Principles and Practices of Rice Production (No. 633.18 D2622p Ej. 2 019781). John Wiley \& Sons.

Dengiz, O., Özyazici, M.A., Sağlam, M., 2015. Multi-criteria assessment and geostatistical approach for determination of rice growing suitability sites in Gokirmak catchment Paddy Water Environ. 13, 1. https://doi-org.ezproxy.nottingham.ac.uk/10.1007/ s10333-013-0400-4.

Drescher, G.L., da Silva, L.S., Sarfaraz, Q., Roberts, T.L., Nicoloso, F.T., Schwalbert, R., Marques, A.C.R., 2020. Available nitrogen in paddy soils depth: influence on rice root morphology and plant nutrition. J. Soil Sci. Plant Nutr. 20 (3), 1029-1041.

ESA, 2017. Land Cover CCI Product User Guide Version 2. Tech. Rep.. http://maps.elie. ucl.ac.be/CCI/viewer/download.php (Accessed on 20th July 2019).

FAO, 1976. A Framework for Land Evaluation. FAO Soil Bulletin No. 32. FAO, Rome.

FAO, 1983. Guidelines: land evaluation for rainfed agriculture food and agriculture organization of the United Nations. Soils Bulletin 52. http://www.fao.org/3/x60 83f/x6083f00.htm.

FAO, 1985. Guidelines: Land Evaluation for Irrigated Agriculture. Food and Agriculture Organization of the United Nations. http://www.fao.org/docrep/X5648E/X56 48E00.htm.

FAO, 2006. Guidelines for Soil Description. http://www.fao.org/3/a-a0541e.pdf.

Fick, S.E., Hijmans, R.J., 2017. WorldClim 2: new $1 \mathrm{~km}$ spatial resolution climate surfaces for global land areaIntl. J. Climatol. 37 (12), 4302-4315. https://www.worldclim. org.

Golden, B.L., Wang, Q., 1990. An alternative measure of consistency. In: Golden, B.L., Wasil, A., Harker, P.T. (Eds.), Analytic Hierarchy Process: Applications and Studies. Springer Verlag, New-York, pp. 68-81.

Government of the Republic of Zambia (GRZ), 1991. Exploratory Soil Map of Zambia (1: $1.000,000)$.

Hengl, T., de Jesus, J.M., Heuvelink, G.B., Gonzalez, M.R., Kilibarda, M., Blagotić, A., Shangguan, W., Wright, M.N., Geng, X., Bauer-Marschallinger, B., Guevara, M.A., 2017. SoilGrids250m: global gridded soil information based on machine learning. PLoS One 12 (2). https://doi.org/10.1371/journal.pone.0169748.

IIASA/FAO, 2012. Global Agro-ecological Zones (GAEZ v3.0). IIASA, Laxenburg, Austria and FAO, Rome, Italy.

ISRIC -World Soil Information, 2017. SoilGrids250m: Global Gridded Soil Information. Available. https://soilgrids.org.

Johnson, A.K.L., Cramb, R.A., McAlpine, J.R., 1994. Integrated land evaluation as an aid to land use planning in northern Australia. J. Environ. Manag. 40 (2), 139-154.

Lark, R.M., Gillingham, V., Langton, D., Marchant, B.P., 2020. Boundary line models for soil nutrient concentrations and wheat yield in national-scale datasets. Eur. J. Soil Sci. https://doi.org/10.1111/ejss.12891 (in press)

Malczewski, J., 1999. GIS and Multicriteria Decision Analysis. John Wiley \& Sons.

Masoud, J., Agyare, W.A., Forkuor, G., Namara, R., Ofori, E., 2013. Modeling inland valley suitability for rice cultivation. ARPN J. Eng. Appl. Sci. 8 (1), 9-19.
Massawe, B.H., Kaaya, A.K., Slater, B., 2019. Involving Small Holder Farmers in the Agricultural Land Use Planning Process Using Analytic Hierarchy Process in Rice Farming Systems of Kilombero Valley, Tanzania.

Ministry of Agriculture, 2016. Second National Rice Development Strategy (2016-2020). Ministry of Agriculture.

Mohammed, H.G., 2011. Land Suitability Evaluation for Some Selected Land Use Types in the Institute for Agricultural Research Farm, Zaria, Nigeria ( $\mathrm{PhD}$ thesis). Ahmmadu Bello University.

Mokarram, M., Aminzadeh, F., 1996. GIS-based multicriteria land suitability evaluation using ordered weighted averaging with fuzzy quantifier: a case study in Shavur Plain, Iran. Int. Arch. Photogramm. Remote. Sens. Spat. Inf. Sci. 38, 508-512.

Moormann, F.R., Van Breemen, N., 1978. Rice: soil, water, land. International Rice Research Institute, Los Baños, Philippines.

Moreno, J., Sánchez, F., 2007. Applicability of Knowledge Based and Fuzzy Theory Oriented Aproaches to Land Suitability for Upland Rice and Rubber, as Compared to the Farmers' Perception: A Case Study of Lao PDR. ITC.

Munene, P., Chabala, L., Mweetwa, M., 2017. Land suitability assessment for soybean (Glycine max (L.) Merr.) production in Kabwe District, Central Zambia. J. Agric. Sci. 9 (3), 1-16. https://doi.org/10.5539/jas.v9n3p74.

Mutale, C., Lungu, D.M., Muuka, F.P., Books, R.U.F.O.R.U.M., OER, R., SCARDA, R. and Tenders, R.U.F.O.R.U.M, 2010. Adaptability of rice cultivars to different ecologies in western province of Zambia. In: Second RUFORUM Biennial Regional Conference on "Building capacity for food security in Africa", Entebbe, Uganda, 20-24 September 2010, pp. 421-424.

Nguyen, H., Nguyen, T., Hoang, N., Bui, D., Vu, H., Van, T., 2020. The application of LSE software: a new approach for land suitability evaluation in agriculture. Comput. Electron. Agric. 173, 105440. https://doi.org/10.1016/j.compag.2020.105440.

Ojara, M., Ann, O., Lawrence, A., Ogwang, B.A., Peter, W., 2017. Predicting suitability of upland rice for adoption as food security and poverty alleviation crop in Uganda. J. Geogr. Earth Sci. 5 (1), 26-40. https://doi.org/10.15640/jges.v5n1a2.

Olaleye, A.O., Ogunkunle, A.O., Sahrawat, K.L., Osiname, O.A., Ayanlaja, S.A., 2002. Suitability Evaluation of Selected Wetland Soils in Nigeria for Rainfed Rice Cultivation. Tropicultura 20 (3), 97-103.

Poggio, L., de Sousa, L.M., Batjes, N.H., Heuvelink, G.B.M., Kempen, B., Rossiter, D., 2021. Producing soil information for the globe with quantified spatial uncertainty. SOIL 7, 217-240. https://doi.org/10.5194/soil-7-217-2021.

R Core Team, 2019. R: A Language and Environment for Statistical Computing. $\mathrm{R}$ Foundation for Statistical Computing, v3.6.2. Vienna, Austria. http://www.R-pro ject.org/.

Rossiter, D.G., 1995. Economic land evaluation: why and how. Soil Use Manag. 11 (3), 132-140. https://doi.org/10.1111/j.1475-2743.1995.tb00511.x.

Saaty, T.L., 1980. The Analytic Hierarchy Process McGraw-Hill. New York, 324.

Saaty, T.L., 1988. What is the analytic hierarchy process. In: Mitra, G., Greenberg, H.J., Lootsma, F.A., Rijkaert, M.J., Zimmermann, H.J. (Eds.), Mathematical Models for Decision Support. NATO ASI Series (Series F: Computer and Systems Sciences), vol 48. Springer, Berlin, Heidelberg. https://doi.org/10.1007/978-3-642-83555-1_5.

Singha, C., Swain, K.C., 2016. Land suitability evaluation criteria for agricultural crop selection: a review. Agric. Rev. 37 (2), 125-132.

Stern, R.D., Cooper, P.J.M., 2011. Assessing climate risk and climate change using rainfall data-a case study from Zambia. Exp. Agric. 47 (2), 241-266.

Styger, E., 2014. Rice Production Diagnostic for Chinsali (Chinsali District, Northern Province) and Mfuwe (Mwambe District, Eastern Province), Zambia (No. July). COMACO/Center for Sustainable Development.

Styger, E., Uphoff, N., 2016. The System of Rice Intensification (SRI): revisiting agronomy for a changing climate. Clim.-Smart Pract. Brief 1-11. https://hdl.handle. net/10568/77040. (Accessed 28 February 2020).

Suheri, N.A., Mujiyo, M., Widijanto, H., 2018. Land suitability evaluation for upland rice in Tirtomoyo District, Wonogiri Regency, Indonesia. SAINS TANAH - J. Soil Sci. Agroclimatol. 15 (1), 46.

Sys, C., Van Ranst, E., Debaveye, J., Beernaert, F., 1993. Land evaluation. Part III: crop requirements. In: Agricultural Publications, 7. GADC, Brussels, Belgium, pp. 1-191. https://www.researchgate.net/publication/324330469_Land_Evaluation_Part_3_ Crop_Requirements.

Tanasă, I.C., Niculită, M., Roşca, B., Pîrnău, R., 2010. Pedometric techniques in spatialisation of soil properties for agricultural land evaluation. Bull. Univ. Agric. Sci. Vet. Med. Cluj-Napoca. Agric. 67 (1).

United States Geological Survey (USGS), 2019. NASA Shuttle Radar Topography Mission (SRTM3) Data Available on the World Wide Web. https://earthexplorer.usgs.gov (accessed 10 July, 2019).

Yohannes, H., Soromessa, T., 2018. Land suitability assessment for major crops by using GIS-based multi-criteria approach in Andit Tid watershed, Ethiopia. Cogent Food Agric. 4 (1), 1470481. 